\title{
Legal instruments for the development of the European Labour Market
}

\author{
Dagmara Skupień
}

$\begin{array}{ll}\text { Introduction } & 75\end{array}$

A. Institutional framework $\quad 77$

I. The Advisory Committee $\quad 77$

II. The Technical Committee $\quad 78$

III. European Coordination Office 79

B. EURES $\quad 80$

C. Support of migration of young workers and graduates 82

D. Solvit network

E. Mutual recognition of professional qualifications 86

I. Basic notions $\quad 86$

II. Levels of professional qualifications $\quad 87$

III. Compensatory measures $\quad 88$

$\begin{array}{ll}\text { IV. Procedural rules } & 90\end{array}$

V. ECJ jurisprudence $\quad 90$

Conclusions $\quad 93$

Introduction

The free movement of workers in the EU is supported by instruments which aim at facilitating the transnational mobility of job-seekers. These instruments have the legal basis in Article 46 TFEU (ex. Article 40 TEC) which gives the competence to the European Parliament and the Council to issue directives or make regulations setting out measures required to bring about freedom of movement for workers in particular by ensuring close cooperation between national employment services, by abolishing any administrative procedures, practices or qualifying periods in respect of eligibility for available employment, the maintenance of which would form an obstacle to liberalization of the movement of workers and by setting up appropriate machinery to match the demand and supply of work in the EU. 
The most important EU legal instruments which aim at eliminating barriers at the free movement of job-seekers and setting-up of the European Labour Market are the transnational cooperation for vacations' clearance EURES, the transnational system of disputes' solving (SOLVIT), special programs for the support of the young workers' mobility and the system of mutual recognition of professional qualifications.

The legal framework for setting up such instruments is provided for firstly in the Regulation No 492/2011 on freedom of movement for workers within the Union ${ }^{1}$ which codifies the former Regulation (EEC) No 1612/682. According to Article 5 of this Regulation, a national of a Member State who seeks employment in the territory of another Member State shall receive the same assistance there as that afforded by the employment offices in that State to their own nationals seeking employment. On the basis of the former Regulation No 1612/1968, specialized organs have been set up to promote and facilitate the free movement of workers, namely the Advisory Committee and the Technical Committee.

The Regulation No 492/2011 also provides for the legal basis for the policy of clearance of vacancies and proceeding within the applications for employment in the EU Member States. This policy is based on the co-operation between the specialized employment services of the Member States and the European Commission (Articles 1120). This cooperation is organized by the European Office for Coordinating the Clearance of Vacancies and Applications for Employment (the 'European Coordination Office', also called EURES Coordination Office) which is managed by the DirectorateGeneral for Employment and Social Affairs of the European Commission.

As it concerns the system of the mutual recognition of professional qualifications, the main principles of it were firstly established in the case-law of the European Court of Justice $^{3}$. The case-law was then codified in a series of directives 4 : among which the sectoral directives, that concerned particular professions like the profession of architect and medical professions and directives of general scope of application establishing the system of recognition of qualifications and diplomas, respectively, the diplomas of

1 Regulation (EU) No 492/2011 of the European Parliament and of the Council of 5 April 2011 on freedom of movement for workers within the Union, OJ L 141/1, 27.5.2011, p. 1-12.

2 Regulation (EEC) No 1612/68 of the Council of 15 October 1968 on freedom of movement for workers within the Community, OJ L 257, 19.10.1968, p. 2-12.

3 See for example ECJ judgments in cases: Judgment of 28 April 1977, C-71/76 - Thieffry v. Conseil de l'Ordre des Avocats, [1997] ECR, p. 765, Judgment of 7 May 1991, C-340/89 - Vlassopoulou v. Ministerium für Justiz, Bundes- und Europaangelegenheiten Baden-Württemberg, [1991] ECR, p. I2357 and Judgment of 12 July 1984, C-107/83 - Ordre des avocats au Barreau de Paris v. Onno Klopp, [1984] ECR, p. 2971.

4 On the content of these directives see i.a. R. Blanpain, European Labour Law, 12th revised edition Alphen aan den Rijn 2010, p. 352-354. 
higher education lasting at least three years ${ }^{5}$, the post-secondary school diplomas ${ }^{6}$, and the recognition of qualifications in the areas of craft, trade and industry 7 .

Further to the Communication from the Commission entitled „New European Labour Markets, Open to All, with Access to All", the European Council of Stockholm on 23 and 24 March 2001 entrusted the Commission with presenting for the 2002 Spring European Council specific proposals for a more uniform, transparent and flexible regime of recognition of qualifications. The above-mentioned directives were consolidated by the Directive 2005/36/EC of the European Parliament and of the Council of 7 September 2005 on the recognition of professional qualifications ${ }^{8}$ which is currently under revision ${ }^{9}$.

\section{A. Institutional framework}

\section{The Advisory Committee}

According to Article 21 of the Regulation No 492/2011, the Advisory Committee is responsible for assisting the Commission in the examination of any questions arising from the application of the EU provisions concerning the freedom of movement of workers and their employment. The Advisory Committee is responsible in the light of Article 22 of the Regulation in particular for examining problems concerning freedom of movement and employment within the framework of national manpower policies with a view to coordinating the employment policies of the Member States at the Union level, making a general study of the effects of implementing the Regulation or supplementary measures and submitting to the Commission any reasoned proposals for revising this Regulation, delivering either at the request of the Commission or on its own initiative, reasoned opinions on general questions or on questions of principle on ex-

5 Council Directive 89/48/EEC of 21 December 1988 on a general system for the recognition of higher-education diplomas awarded on completion of professional education and training of at least three years' duration, OJ L 19, 24.1.1989, p. 77-93.

6 Council Directive 92/51/EEC of 18 June 1992 on a second general system for the recognition of professional education and training to supplement Directive 89/48/EEC, OJ L 209, 24.7.1992, p. 2545.

7 Directive 1999/42/EC of the European Parliament and of the Council of 7 June 1999 establishing a mechanism for the recognition of qualifications in respect of the professional activities covered by the Directives on liberalization and transitional measures and supplementing the general systems for the recognition of qualifications, OJ L 201, 31.7.1999, p. 77-93.

8 Directive 2005/36/EC of the European Parliament and of the Council of 7 September 2005 on the recognition of professional qualifications, OJ L 255, 30.9.2005, p. 22-142.

9 See Proposal for a Directive of the European Parliament and of the Council amending Directive 2005/36/EC on the recognition of professional qualifications and Regulation [...] on administrative cooperation through the Internal Market Information System of 19.12.2011, COM(2011) 883 final. 
change of information concerning developments in the labour market, on the movement of workers between Member States, on programs or measures to develop vocational guidance and vocational training which are likely to increase the possibilities of freedom of movement and employment and on all forms of assistance to workers and their families, including social assistance and the housing of workers.

The Advisory Committee is composed of tripartite national delegations from each Member State, two representatives of respectively the government, the trade unions and the employers' organizations (additionally one alternate member shall be appointed by each Member State). The term of office of the members and their alternates is two years ${ }^{10}$. The present term runs till September 2012. The members of the Advisory Committee and their alternates are appointed by the Council which shall endeavour, when selecting representatives of trade unions and employers' associations, to achieve adequate representation on the Committee of the various economic sectors concerned ${ }^{11}$.

The Advisory Committee is chaired by a member of the Commission or his representative. The Chairman is not entitled to vote. The Advisory Committee shall meet twice a year. At its meetings individuals or representatives of bodies with wide experience in the field of employment or movement of workers may take part as observers. The Chairman may also be assisted by expert advisers ${ }^{12}$.

\section{The Technical Committee}

The Technical Committee is responsible for assisting the Commission in the preparation, promotion and follow-up of all technical work and measures for giving effect to the Regulation and to any supplementary measures ${ }^{13}$.

The tasks of the Technical Committee cover especially promoting and advancing cooperation between the public authorities concerned in the Member States on all technical questions relating to freedom of movement of workers and their employment; formulating procedures for the organization of the joint activities of the public authorities concerned; facilitating the gathering of information likely to be of use to the Commission and the undertaking of the studies and research provided for in this Regulation, and encouraging the exchange of information and experience between the administrative bodies concerned as well as investigating at a technical level the harmonization of the criteria by which Member States assess the state of their labour markets ${ }^{14}$.

The composition of the Technical Committee is linked with the membership in the Advisory Committee. The Technical Committee is composed of representatives of the

10 Article 23 of the Regulation No 492/2011.

11 Article 24 of the Regulation No 492/2011.

12 Article 26 of the Regulation No 492/2011.

13 Article 29 of the Regulation No 492/2011.

14 Article 30 of the Regulation No 492/2011. 
governments of the Member States (one governmental member of the Advisory Committee). Moreover, each government shall appoint an alternate from any of three categories of members to the Advisory Committee ${ }^{15}$. Similarly, as it concerns the Advisory Committee, the Technical Committee is chaired by a member of the Commission or his representative, who does not have the right of vote. The Committee members and the Chairman are assisted by expert advisers. Any proposals or opinions of the Technical Committee are submitted to the Commission and the Advisory Committee shall be informed about them.

\section{European Coordination Office}

The European Coordination Office (EURES Coordination Office) functions on the basis of Articles 18-20 of the Regulation No 492/2011. Its general task is promoting vacancy clearance at the level of the European Union. It is responsible for all the technical duties in this field which are assigned to the Commission and especially for assisting the national employment services ${ }^{16}$ (Article 18 para. 1 of the Regulation). The European Coordination Office summarizes all the information and data obtained from the studies and research carried out by the Member State and the Commission to make public any useful fact about the foreseeable developments on the Union labour market. It informs thereof the specialized services of the Member States, the Advisory Committee and the Technical Committee.

The particular duties of the European Coordination Office cover: a) coordination of practical measures necessary for vacancy clearance at Union level and for analyzing the resulting movements of workers, $b$ ) implementation of joint methods of action at administrative and technical levels (in co-operation with the Technical Committee), c) matching of vacancies and applications for employment where a special need arises and in agreement with the specialist services. The European Coordination Office shall also communicate to the specialist services vacancies and applications for employment sent directly to the Commission ${ }^{17}$.

15 Article 31 of the Regulation No 492/2011.

16 On European Coordination Office see also M. Kurzynoga, Gwarancje i ułatwienia swobody przepływu (Guarantees and facilities to the free movement), in: Z. Hajn (ed.), Swobodny przepływ pracowników wewnątrz Unii Europejskiej (Free movement of employees in the European Union), Warsaw 2010, p. 176-177.

17 Article 19 of the Regulation No 492/2011. 


\section{B. EURES}

The European Employment Services network (EURES) is a cooperation network which promotes the mobility of workers within the European Economic Area and also in Switzerland ${ }^{18}$. It was established in $1993^{19}$. The principles of its functioning are nowadays regulated by the Commission Decision 2003/8/EC of 23 December $2002^{20}$ and the EURES Charter of 26 October $2010^{21}$.

In the light of point 1.1. of the EURES Charter, the EURES activities relating to the increase of mobility are carried out according to the principle of 'fair mobility', particularly fighting undeclared work and social dumping with the aim to ensure that labour standards and legal requirements are always fully respected.

EURES is composed of EURES members (the specialist services appointed by the Member States and the European Coordination Office) and the EURES partners (social partners' organizations, regional employment services of the Member States and employment services responsible for border regions). The European Coordination Office co-ordinates the activities of EURES and especially undertakes the analyses of mobility, develops the cooperation and coordination between the Member States, monitors and evaluates the EURES activity. The organs which assist the EURES are High Level Strategy Group and the EURES Working Party. The first one is composed of the chiefs of the EURES members chaired by a representative of the Commission and assists the Commission in promoting and overseeing the development of EURES. The Working Party is composed of EURES managers, each one representing a EURES member. It assists the development, implementation and monitoring of EURES activities.

The main activities of EURES are job-matching services, development of transnational sectoral and cross-border cooperation as well as monitoring, assessing and dealing with obstacles to mobility 22 .

Within the job-matching services the EURES members and partners should inform, guide and provide advice to potentially mobile workers on job opportunities. In particular they shall supply the job-seekers with the valid, accurate and sufficient information on vacancies in order to allow them to make an informed decision about applying. The EURES members and partners shall also help and give assistance to job-seekers in drawing up of applications and CVs according to the recommended European CV for-

18 See the official webpage of EURES: http://ec.europa.eu/eures/.

19 On the basis of Commision Decision 93/569/EEC.

20 Commission Decision of 23 December 2002 implementing Council Regulation (EEC) No 1612/68 as regards the clearance of vacancies and applications for employment, OJ L 005, 10.1.2003, p. 1619.

21 The European Coordination Office, EURES Charter, OJ C 311/6, 16.11.2010.

22 On the activities of EURES, see also J.-M. Servais, Droit social de l'Union européenne, Brussels 2008, p. 160-161 and M. Kurzynoga, Gwarancje i ułatwienia swobody przepływu (Footnote 16), p. 179-184. 
mat. The job-seekers have also a possibility of registration in the EURES CV database. As it concerns the employers who wish to recruit workers from other countries they are given advice and help to specify the profile of the potential candidates. EURES also promotes the EURES CV database among the employers. Another service of EURES concerns the supply of the information on living and working conditions in the European Economic Area.

Moreover, EURES members and partners which specialize in certain occupations or employment of special categories of persons such as management or research staff should support the cooperation in these sectors. EURES members with local social partners, local authorities and other relevant local and regional organizations also provide advice and guidance to workers and employers in cross-border regions.

EURES activities cover monitoring, assessment and dealing with obstacles to mobility, especially monitoring the existence of specific surpluses and shortages of skilled workers and tracking obstacles such as for example differences in legislation and administrative procedures.

The EURES services are usually free of charge. The services are carried out by a qualified staff: managers and advisers. EURES advisers work in the framework of one of the EURES member or partner organizations. They are trained specialists who provide the three basic EURES services of information, guidance and placement, to both jobseekers and employers interested in the European job market.

As it was earlier indicated, one of the main services of the EURES network is to provide advice and guidance to workers and employers in cross-border regions (EUREST). EURES promotes the cooperation in cross-border areas together with local social partners, local authorities and other relevant local and regional organizations. The most important role is to play by EURES in these cross-border regions where there is a significant level of cross-border commuters.

According to data published by EURES ${ }^{23}$, there are at present over twenty crossborder partnerships in the EU which involve more than thirteen countries. In the area of three borders: Polish, German and the Czech one, there exists a EURES-TriRegio partnership which comprises the employment markets of the subregion of JeleniogórskoWałbrzyski in the voivodship of Dolnośląskie in Poland, the districts of Ústí nad Labem, Karlovy Vary and Liberec in the Czech Republic and the administrative districts of Chemnitz and Dresden in the Saxony in Germany ${ }^{24}$. This partnership consists of the governmental labour administration, public employment services, trade unions and employers' organizations. It was formally established in October 2007. The EURES TriRegio cross-border partnership aims at integration of the employment and training markets and in the longer perspective at the development of a common employment market. The EURES-TriRegio supports the job-seekers, employers, self-employed per-

23 See EURES webpage: http://ec.europa.eu/eures/.

24 For more data on the functioning and achievements of this partnership see: http://www.eurestriregio.eu/. 
sons, trainees and students with information, advice and placement services in the crossborder area. It organizes a variety of events like workshops, expert forums and public events like cross-border advice days, annual job fairs and recruitment days.

Even though EURES has been functioning since 1993, and the network consists of around 850 advisors across Europe ${ }^{25}$, the use of it is very narrow. According to the data presented by Eurobarometer in 2010, only 12\% of Europeans have heard of EURES and only $2 \%$ of respondents have actually used EURES. $85 \%$ of the Europeans living in EU15 countries say they have never heard of EURES (75\% in NMS12). As it concerns Poland, the data show that $76 \%$ of population have not heard of EURES before and among those who have heard of it $(16 \%)$, only $3 \%$ of respondents have used it. In Germany, these data are respectively $83 \%, 9 \%$ and $2 \% 26$.

The highest level of citizens who have heard of EURES exists in Estonia, Slovakia (33\%) and Slovenia (31\%). On the contrary, 93\% of the French, 91\% of the British citizens or the Belgians $(90 \%)$ have never heard of EURES. The biggest percentage of respondents who have used this network live in Finland and Estonia ${ }^{27} .20 \%$ of respondents who envisage working abroad say they have used and/or heard of EURES, whereas this declaration was given only by $12 \%$ of those EU citizens who had no such plans 28 .

As it concerns the scope of services respondents want to be provided with by EURES, half of them find useful the information about job vacancies in another country. On the second place, $40 \%$ of the respondents would like to receive information about the administrative issues related to living and working abroad, 33\% would like help with settling in a host country. One quarter (24\%) would appreciate help in preparing for their move and $18 \%$ would like help with returning to a home country. From the point of view of acquiring knowledge about the EURES network, the percentage of people aware of the existence of such a system is higher among those who have studied abroad $(75 \% \text { vs. } 84 \%)^{29}$.

\section{Support of migration of young workers and graduates}

The European Union undertakes different activities to support the mobility of young job-seekers. Article 47 FUE states that Member States shall, within the framework of a joint program, encourage the exchange of young workers. The support of the young

25 See Eurobarometer 337 (6/2010) „Geographical and labour market mobility”, p. 44.

26 See ibidem, p. 45.

27 Ibidem.

28 Ibidem.

29 See ibidem, p. 54. 
workers' migration seems desirable as one of the tools in mitigating the unemployment of the youth which reached a height of $21 \%$ in $2010^{30}$.

The improvement of the employment situation of young people as well as the promotion of students' and trainees' mobility is included as one of the aims of the initiative „Youth on the move" proposed by the European Commission within the European strategy for smart, sustainable and inclusive growth ${ }^{31}$. The proposed initiative aims at facilitating the young people's entry into the labour market through i.a. developing modern education and training systems, supporting transnational learning and employment mobility for young people. Within the EURES network, the Commission has proposed a scheme „Your first EURES job”, dedicated to young people with the purpose to help them to find a job in any of the EU-27 Member States and moving abroad. Another initiative which has started in 2010 is a European Vacancy Monitor which shows young people and employment advisers where there are jobs in Europe and which skills are needed. The variety of programs financially supported by the EU aim at increasing the European mobility of different groups of young people as i.a. Erasmus, Leonardo da Vinci, Comenius and Grundtvig programs.

\section{Solvit network}

Solvit is an on-line informal problem solving network in which EU Member States co-operate to solve without legal proceedings problems caused by the misapplication of internal market law by public authorities ${ }^{32}$. Solvit network has been working since 2002 33 . The initiative of SOLVIT network was built upon the previous Co-ordination Centres which have been established in 1997 to deal with such problem cases arising in relation to the mobility on the internal market. In 2001 the Commission has proposed to set up a new mechanism, namely a SOLVIT network ${ }^{34}$. The importance of such an initiative was underlined in the Council conclusions on the "SOLVIT" network issued on the $1^{\text {st }}$ March 2002. The main reason for setting up of this mechanism was that the practice of functioning of Co-ordination Centres showed shortcomings such as a different

30 See Communication from the Commission to the European Parliament, the Council, the European Economic and Social Committee and the Committee of the Regions, Youth on the Move. An initiative to unleash the potential of young people to achieve smart, sustainable and inclusive growth in the European Union, $\operatorname{COM}(2010) 477$ final, p. 1.

31 See Communication from the Commission, EUROPE 2020, A strategy for smart, sustainable and inclusive growth, $\operatorname{COM}(2010)$ 2020, p. 11.

32 See Solvit webpage: http://ec.europa.eu/solvit/.

33 On Solvit see i.a. M. Kurzynoga, Gwarancje i ułatwienia swobody przepływu (Footnote 16), p. 185188.

34 See Communication from the Commission to the Council, the European Parlament, the Economic and Social Committee and the Committee of the Regions - Effective Problem Solving in the Internal Market (,SOLVIT”), COM(2001) 702 final. 
standard of case treatment in Member States, especially slowness on the part of other Member States to respond to inquiries, lack of knowledge on whom to contact in the other Member State, time-consuming and costly translation of documents ${ }^{35}$. The Commission has set up the principles for the functioning of the SOLVIT network in the recommendation of 7 December 200136. The European Commission coordinates the network, provides the database facilities and helps to solve the problems in a good time.

The SOLVIT is competent for finding solutions to the cross-border problems, i.e. problems confronting an individual or a business in a Member State involving the application of Internal Market rules by a public authority in another Member State. This scope includes situations where a citizen or a business having an administrative link with one Member State (like nationality, qualifications or establishment) is already in the second Member State where the problem occurs. The SOLVIT centres do not deal with problems which are subject to the legal proceedings initiated at national or Union level. The areas covered by SOLVIT are i. a. residence rights, social security rights and recognition of professional qualifications.

Apart the cases which concern the improper application by the public administration of the EU rules, there are also SOLVIT + cases which concern the litigations which arise from the bad implementation of EU directives in the Member States or the improper guidelines issued for the national organs. Certain SOLVIT centres like centres in Denmark or in Germany reject such cases as falling beyond the scope of competence of SOLVIT but the majority of SOLVIT centres take them ${ }^{37}$.

The SOLVIT network relies on the activities of the Coordination Centres. These Centres make part of the national administration (in Poland SOLVIT functions at the Ministry of Economy, in Germany at the Federal Ministry for Economy and Technology). There are two types of Coordination Centres ${ }^{38}$ : Home Coordination Centre and the Lead Coordination Centre. The first one is the Coordination Centre in the Member State in which the cross-border problem was raised. The latter one is the centre in the Member State in which the cross-border problem occurred. The Home Coordination Centre which receives the case should register it in the online database and transmit all the necessary information to the Lead Coordination Centre which is responsible for the solution of the cross-border case. The Lead Centre confirms the acceptance of the case within one week and forwards it to the appropriate part of its administration for action. The deadline for solving problems is ten weeks. In exceptional cases, the Home and Lead Coordination Centres may agree to extend the deadline by up to four weeks if they con-

35 See Communication from the Commission to the Council, the European Parlament, the Economic and Social Committee and the Committee of the Regions - Effective Problem Solving in the Internal Market (,SOLVIT”), COM(2001) 702 final, point 5.1.2.

36 Commission Recommendation of 7 December 2001 on principles for using „SOLVIT” - the Internal Market Problem Solving C 2001-3901, OJ L 331, 15.12.2001, p. 79-82.

372009 Report, Development and Performance of the SOLVIT network, http://ec.europa.eu/solvit/, p. 12.

38 See Commission Recommendation on principles for using „SOLVIT”. 
sider it probable that a solution can be found within that time. If the solution is found to the problem, the Home and Lead Coordination Centres confirm their agreement that the problem is effectively solved and this fact is registered in the database. Similarly, in the situation that the Lead Coordination Centre decides the case is unfounded, it should register this fact in the database. The applicant may initiate formal proceedings on this stage.

The activities of Solvit are summarized in the yearly report. According to the data concerning $2009^{39}$ the number of cases conferred to the SOLVIT network increases every year (in 2003 almost 200 cases against almost 1600 cases in 2009). However, the complaints from businesses were at the same level whereas throughout these years a substantial increase was observed in relation to the citizens' complaints ${ }^{40}$. The cases related to the free movement of persons had constituted a large number of cases filed to the SOLVIT centres, the complaints concerning the residence rights amounted to $38 \%$, $15 \%$ of the complaints concerned the recognition of professional qualifications, $23 \%$ were related to social security, and $2 \%$ of the complaints were related to employment rights $^{41}$. In the area of recognition of professional qualifications, the SOLVIT centres tackled for example cases concerning the delays in processing applications for recognition, decisions proposing compensatory measures without justification or without precise information on the length of the compulsory traineeship or the way to apply for it; or even decisions on the compensatory measure accompanied by the informal information that no courses to comply with the measure were available as well as the delays of national authorities in setting up expert committees to examine the applicants' knowledge ${ }^{42}$. As it concerns the social security problems, it concerned especially the delays in issuing health insurance certificates, late payments of social benefits or problems concerning transfer of pension rights ${ }^{43}$. The cases in the realm of residence rights related i.a. to delays in issuing the residence cards for the family members from the third country or conflicts over the interpretation of the durable partnership ${ }^{44}$.

392009 Report, Development and Performance of the SOLVIT network, p. 6, http://ec.europa.eu/solvit/.

40 Ibidem, p. 7.

41 Ibidem, p. 8.

42 Ibidem, p. 10.

43 Ibidem, p. 9.

44 Ibidem, p. 8. 


\section{E. Mutual recognition of professional qualifications}

\section{Basic notions}

According to the European Commission's estimates ${ }^{45}$, at present twenty-seven Member States regulate around four thousand seven hundred professions on the basis of a professional qualification. Article 3 para. 1 point a) of the Directive 2005/36/EC defines the notion of the regulated profession as a: ,a professional activity or a group of professional activities, access to which, the pursuit of which, or one of the modes of pursuit of which is subject, directly or indirectly, by virtue of legislative, regulatory or administrative provisions to the possession of specific professional qualifications; in particular, the use of a professional title limited by legislative, regulatory or administrative provisions to holders of a given professional qualification shall constitute a mode of pursuit $[\ldots]$ ". On the basis of Article 3 para. 2 of the Directive, also a profession practiced by the members of the association or the organization listed in the Annex 1 to the Directive $^{46}$ shall be treated as a regulated profession.

The Directive 2005/36/EC distinguishes three systems of recognition: the system of automatic recognition of qualifications confirmed by the professional experience in the area of craft, trade and industry, the system of recognition for particular professions: doctors of medicine, nurses of general care, dentists, veterinary surgeons, midwives, pharmacists and architects (sectoral system) and the general system of recognition of professional qualifications. The first of these systems is principally based on the recognition of professional experience, the duration of which is precisely described in the Directive. The second system relies on the coordination of minimum training conditions for each of the profession.

The general system of recognition concerns the regulated professions which do not fall under the scope of two other systems. Persons who acquired professional qualifications for the particular profession within the sectoral provisions but do not meet requirements set up in this system may also profit from the general system.

Preliminarily, it should be acknowledged that temporary provision of services in the host country may be carried out on the basis of the professional title acquired in the Member State of origin. In such a case, a host Member State may only require a prior declaration accompanied by a number of documents to be sent to the competent authority. The necessity to obtain the recognition of professional qualifications concerns persons who seek employment or the self-employment in the host Member State.

45 See European Commission, Green Paper, Modernizing the Professional Qualifications Directive, $\operatorname{COM}(2011) 367$ final, p. 7.

46 Annex 1 concerns the professional associations and organizations set up in Ireland and in the United Kingdom. 
The system of mutual recognition of qualifications is based on the principle established in Article 13 para. 1 of the Directive 2005/36/EC which states that if access to or pursuit of a regulated profession in a host Member State is contingent upon possession of specific professional qualifications, the competent authority of that Member State shall permit access to and pursuit of that profession, under the same conditions as apply to its nationals, to applicants possessing the attestation of competence or evidence of formal qualifications required by another Member State in order to gain access to and pursue that profession on its territory.

According to Article 1 para. 1 (c) of the Directive, the „evidence of formal qualifications" is defined as diplomas, certificates and other evidence issued by a competent authority in a Member State designated pursuant to legislative, regulatory or administrative provisions of that Member State and certifying successful completion of professional training obtained mainly in the Community. Moreover, the evidence of formal qualifications issued by a third country shall be regarded as the evidence of formal qualifications if the holder has three years' professional experience in the profession concerned on the territory of the Member State which recognized that evidence of formal qualifications (Article 1 para. 3 of the Directive). The Directive helps thus the EU citizens to get recognized the qualifications acquired in the third countries.

\section{Levels of professional qualifications}

Article 11 of the Directive 2005/36/EC establishes five, quite complicated, hierarchical levels of professional qualifications. The first level relates to attestations of competence issued on the basis of (a) either a training course not forming part of a certificate or diploma of a successful completion of a secondary or a post-secondary course or a specific examination without prior training, or full-time pursuit of the profession in a Member State for three consecutive years or for an equivalent duration on a part-time basis during the previous 10 years or on the basis of b) general primary or secondary education, attesting that the holder has acquired general knowledge.

The second level concerns certificates attesting to a successful completion of a secondary course (a) either general in character, supplemented by a course of study or professional training other than those referred to in the third level below and/or by the probationary or professional practice required in addition to that course, or (b) technical or professional in character, supplemented where appropriate by a course of study or professional training as referred to in point (a), and/or by the probationary or professional practice required in addition to that course.

The third level relates to diplomas certifying successful completion of (a) either training at post-secondary level other than that referred to in the fourth and the fifth level of a duration of at least one year or of an equivalent duration on a part-time basis, one of the conditions of entry of which is, as a general rule, the successful completion of the 
secondary course required to obtain entry to university or higher education or the completion of equivalent school education of the second secondary level, as well as the professional training which may be required in addition to that post-secondary course; or (b) in the case of a regulated profession, training with a special structure, included in Annex $\mathrm{II}^{47}$, equivalent to the level of training provided for under (a), which provides a comparable professional standard and which prepares the trainee for a comparable level of responsibilities and functions.

The fourth level covers diplomas certifying successful completion of training at postsecondary level of at least three and not more than four years' duration, or of an equivalent duration on a part-time basis, at a university or establishment of higher education or another establishment providing the same level of training, as well as the professional training which may be required in addition to that post-secondary course.

The fifth level relates to diplomas certifying that the holder has successfully completed a post-secondary course of at least four years' duration, or of an equivalent duration on a part-time basis, at a university or establishment of higher education or another establishment of equivalent level and, where appropriate, that he has successfully completed the professional training required in addition to the post-secondary course.

The Directive makes the access to the regulated professions more liberal as the evidence of qualifications to be recognized shall attest a level of professional qualifications at least equivalent to the level immediately prior to that which is required in the host Member State, as described in Article 1148. On the other hand, if the level of qualifications is lower than one level, it means that the competent authority is entitled not to recognize it automatically.

\section{Compensatory measures}

Even though the recognition of diplomas and professional qualifications is a principle, according to Article 14 of the Directive, the Member States dispose in certain situations of the right to submit an applicant to the compensation measures. The use of compensation measures is thus allowed if the duration of the training of which he provides evidence is at least one year shorter than that required by the host Member State or the training he has received covers substantially different matters than those covered by the evidence of formal qualifications required in the host Member State or the regulated profession in the host Member State comprises one or more regulated professional activities which do not exist in the corresponding profession in the applicant's home Member State and that difference consists in specific training which is required in the

47 In Poland for ex. a training for a teacher of practical vocational training, in Germany for an optician or a physiotherapist.

48 Article 13 para. $1 \mathrm{~b}$ ) of the Directive. 
host Member State and which covers substantially different matters from those covered by the applicant's attestation of competence or evidence of formal qualifications 49 .

The applicant should be allowed to make a choice between the adaptation period of up to three years and an aptitude test. However, the host Member State may stipulate either an adaptation period or an aptitude test especially for professions whose pursuit requires precise knowledge of national law and in respect of which the provision of advice and/or assistance concerning national law is an essential and constant aspect of the professional activity.

The notion of the adaptation period should be understood as the pursuit of a regulated profession in the host Member State under the responsibility of a qualified member of that profession, such period of supervised practice possibly being accompanied by further training ${ }^{50}$. This period of supervised practice shall be the subject of an assessment.

As it concerns the aptitude test, it is a test limited to the professional knowledge of the applicant, made by the competent authorities of the host Member State with the aim of assessing the ability of the applicant to pursue a regulated profession in that Member State. In order to permit this test to be carried out, the competent authorities shall draw up a list of subjects which, on the basis of a comparison of the education and training required in the Member State and that received by the applicant, are not covered by the diploma or other evidence of formal qualifications possessed by the applicant ${ }^{51}$.

The compensation measures should be applied according to the principle of proportionality. In particular, if the host Member State intends to require the applicant to complete an adaptation period or take an aptitude test, it must first ascertain whether the knowledge acquired by the applicant in the course of his professional experience in a Member State or in a third country, is of a nature to cover, in full or in part, the substantial difference in training. As it concerns the notion of professional experience, it is defined as the actual and lawful pursuit of the profession concerned in a Member State ${ }^{52}$.

The Directive establishes a tool which helps to waive compensatory measures which was not provided for in the previous EU directives, namely common platforms ${ }^{53}$. The notion of the common platform is defined in Article 15 para. 1 of the Directive 2005/36/EC as a set of criteria of professional qualifications which are suitable for compensating for substantial differences which have been identified between the training requirements existing in the various Member States for a given profession. These substantial differences shall be identified by comparison between the duration and contents of the training in at least two thirds of the Member States, including all Member

49 Article 14 para. 1 of the Directive.

50 Article 3 para. $1 \mathrm{~g}$ ) of the Directive.

51 Article 3 para. $1 \mathrm{~h}$ ) of the Directive.

52 Article 3 para. $1 \mathrm{f}$ ) of the Directive.

53 On common platforms see: http://ec.europa.eu/internal_market/qualifications/docs/future/ platforms_en.pdf. 
States which regulate this profession. The differences in the contents of the training may result from substantial differences in the scope of the professional activities.

A common platform may be submitted to the Commission by Member States or by professional associations or organizations which are representative at national and European level. If the Commission, after consulting the Member States, is of the opinion that a draft common platform facilitates the mutual recognition of professional qualifications, it may present draft measures with a view to its adoption. Where the applicant's professional qualifications satisfy the criteria established in the adopted measure, the host Member State shall waive the application of compensation measures.

\section{Procedural rules}

Article 51 of the Directive states that the competent authority of the host Member State shall confirm receipt of the application within one month of receipt and inform the applicant of the lack of any necessary documents. The examination of the application should be completed as quickly as possible and lead to a 'duly substantiated' decision at the latest within three months after the date on which the applicant's complete file has been submitted. This deadline may be extended by one month (except for sectoral provisions). The decision or failure to reach a decision within the prescribed time may be contested according to the national appeal rules.

\section{ECJ jurisprudence}

The complexity of rules on the mutual recognition of professional qualifications led to litigations which were dealt with by European Court of Justice in the preliminary rulings. The judgment in the joined cases C-422/09, C-425/09, C-426/09 (Vandorou and others) ${ }^{54}$ concerned the situation of three applicants to the regulated professions (respectively accountant, mechanical engineer and telecommunications engineer). Each of the applicants in the main proceedings was seeking to pursue a regulated profession in Greece on the basis of his or her authorization to pursue a corresponding regulated profession in another Member State. In each of the three cases the applicants were submitted to the compensatory measures by the Greek Council for the Recognition of the Equivalence of Higher Education Diplomas (the Saeitte) owing to substantial differences in the course of their education in other EU Member States. The Greek authority refused to take into consideration the proofs of the gained practical experience by the applicants on this ground that it was not an experience gained as a person entitled to carry out the given regulated profession.

54 See ECJ Judgment of 2 December 2010, C-422/09 - Case Vandorou, n.y.r. 
The questions asked by the national court aimed at clarifying to what extent the competent authority of the host country is bound to take into account the practical experience which in whole or in part covers those differences. The ECJ has underlined that the professional experience acquired by the applicants does not constitute 'professional experience' in the meaning of the EU directive on the mutual recognition of professional qualifications 55 . Work carried out in one Member State in which authorization to pursue that profession has not yet been acquired, even after obtaining the diploma granting entitlement to pursue the profession in question in another Member State, shall not be regarded as the pursuit of regulated professional activities.

Consequently, the host Member State authority is under no obligation to take into account practical experience gained in that way which does not correspond to the practical experience within the meaning of 'the professional experience' under ex article 1(e) of the Directive 89/48. However, the ECJ invoked in this context the general principles of the EU law, especially the principle of proportionality which must be respected by the national authorities while applying supplementary measures. Moreover, according to the ECJ, the effective exercise of the fundamental freedom of free movement of workers and of the providers of services would be hindered unjustifiably if the competent national authorities for recognition of professional titles acquired in another Member State do not take into account the relevant knowledge and qualifications already acquired by an applicant.

Even though the experience acquired in the course of the pursuit of the given regulated profession in the Member State of origin will, in most cases, be the most relevant for the assessment if the applicant possesses the necessary knowledge to pursue the regulated profession, all practical experience acquired in the pursuit of related activities can increase an applicant's knowledge. Thus the value of such experience should be assessed in the specific functions carried out, knowledge acquired and applied in pursuit of those functions, responsibilities assumed and the level of independence accorded to the person concerned ${ }^{56}$.

The ECJ stated that the pursuit of activities relating to a regulated profession under the control and responsibility of a duly qualified professional in the host Member State allows a person to acquire the 'relevant knowledge of considerable value'. The pursuit of a professional activity supervised by a qualified professional should not be regarded as unlawful since the person concerned is not pursuing the regulated profession herself/himself in such a situation which would be unlawful ${ }^{57}$.

55 The ECJ ruling concerned the provisions of the Council Directive 89/48/EEC of 21 December 1988 on a general system for the recognition of higher-education diplomas awarded on completion of professional education and training of at least three years' duration.

56 Point 69 of the Judgment of 2 December 2010, C-422/09 - Case Vandorou.

57 Point 70 of the Judgment of 2 December 2010, C-422/09 - Case Vandorou. 
In the judgment of the ECJ in case Toki ${ }^{58}$, the ECJ has been analyzing another situation in which the applicant demanded recognition of her right to pursue the regulated profession of environmental engineer in the host Member State (Greece) on that basis that she possessed the qualifications and practical experience in the pursuit of the professional activity of environmental engineer in Great Britain. In the latter country the profession of environmental engineer was not regulated even though the large number of professionals in that field were members and voluntarily respected the Engineering Council's regulatory framework. Ms Toki was not a full member of the Engineering Council and she did not hold the title of Chartered Engineer.

In case Toki, the ECJ stated that in a situation a person is seeking to obtain authorization to pursue a regulated profession in the host Member State on the basis of the professional experience and qualifications acquired in the Member State of origin which does not regulate this profession, three conditions have to be met, namely: a) the experience relied on must consist of full-time work for at least two years during the previous ten years, b) that work must have consisted of the continuous and regular pursuit of a range of professional activities which characterize the profession concerned in the Member State of origin, but that work needs not have encompassed all those activities and c) the profession, as it is normally pursued in the Member State of origin, must be equivalent, in respect of the activities which it covers, to the profession which the person has sought authorization to pursue in the host Member State.

Another situation which may be controversial from the point of view of the recognition of professional qualifications is the partial equivalence of a diploma. This problem was dealt with by the ECJ in the case C-330/03 Colegio de Ingenieros de Caminos, Canales y Puertos ${ }^{59}$. It concerned $\mathrm{Mr}$ Imo who was a holder of an Italian diploma in civil engineering specializing in hydraulics and applied for recognition of his diploma in Spain in order to take up there the profession of civil engineer. The two courses of education and training differed in an important way as it was assessed by the Spanish courts. In a case when the holder of a diploma awarded in one Member State applies for a permission to take up a regulated profession in another Member State, according to the ECJ, Articles 39 TEC (45 TFEU) and 43 TEC (49 TFEU) do not preclude a Member State from not allowing partial taking up of a profession, where shortcomings in the education of training of the party concerned in relation to that required in the host Member State may be effectively made up for through the application of the compensatory measures. However, Articles 39 TEC (Art. 45 TFEU) and 43 TEC (49 TFEU) do preclude a Member State from not allowing that partial taking-up when the party concerned requests so and the differences between the fields of activity are so great that in reality a full programme of education and training is required unless the refusal for that partial taking-up is justified by overriding reasons based on general interest, suitable for

58 ECJ Judgment of 5 April 2011, C-424/09 - Toki v Ipourgos Ethnikis kai Thriskevmaton, n.y.r.

59 ECJ Judgment of 19 January 2006, C-330/03 - Colegio de Ingenieros de Caminos, Canales y Puertos v Administración del Estado, ECR 2006, p. I-801. 
securing the attainment of the objective which they pursue and not going beyond what is necessary in order to attain that objective.

\section{Conclusions}

The free movement of workers within the EU/EEA is supported by a variety of measures which aim at facilitating the migration by levying any obstacles such as refusals to recognize the professional qualifications acquired in the home Member State or by supplying the necessary information concerning the demand for work in other countries or finally solving problems relating to the migration. Big importance is attached by the EU authorities to the support of the young workers' transnational mobility. The EU programs start at the early stage of education offering help in studying abroad and then in finding traineeship or finally employment.

Even though the EU has undertaken important efforts in facilitating the transnational migration, it should be firstly underlined that the barriers in access to regulated professions for non-citizens still persist in Member States what is proved by the ECJ case-law and the big percentage of SOLVIT cases which concern the mutual recognition of qualifications. The biggest problems relate to the differences in the status of professions which may be regulated in the host country and non-regulated in the home country, the differences in the activities of which the regulated profession consists or substantial differences in education. The EU legal framework offers only partially remedies to these problems. The concept of common platforms has turned out to be a failure; no common platform on compensation measures has been developed until 201160 .

For this reason, European Commission has undertaken the task of modernizing the Directive 2005/36/EC. The Commission's legislative proposal aims especially at: the insertion of the principle of partial access following the ECJ case Colegio de Ingenieros de Caminos, Canales y Puertos, reshaping common platforms, setting up of central online access points in Member States offering information on competent authorities and document requirements for the recognition of professional qualifications and allowing for the completion of all formalities online (e-government facilities), making the language requirements less stringent as well as modernizing system of automatic recognition.

As it concerns the system of matching the demand and supply of work in the European Union, it should be noted that the EURES network is not well-known among the EU citizens. As the data show, not a big percentage of the EU citizens dispose of any knowledge about it and make rather a small use of it. Another helpful instrument, name-

60 See European Commission, Green Paper, Modernising the Professional Qualifications Directive, $\operatorname{COM}(2011) 367$ final, p. 6. 
ly SOLVIT, is not a very popular tool neither; even though the number of persons using it increases constantly.

The presented analysis shows that the one, consolidated European Labour Market still is an idea to be attained in the future. However, the efforts undertaken by the EU institutions should be highly appreciated as they make the road to the achievement of this idea much shorter. 